\title{
Ao João
}

António Fazeres

Though the favourites of the gods die young, they also live eternally in the company of gods.

Friedrich Nietzsche, The Birth of Traged $y^{\prime}$

Ouvi-o muitas vezes dizer, citando Heidegger, que há uma arrogância própria da filosofia. Não sob a fonna da sobranceria, mas enquanto altivez que é necessário dar às coisas com as quais há um compromisso radical e inegociável.

Em boa verdade, filosofar é, em primeiro lugar, e acima de tudo, exorcizar os medos, esses inquilinos incómodos alojados no mais recôndito da alma humana, mas é também não temer dizer a verdade, contra qualquer conveniência ou alinhamento ditado exclusivamente pela tradição e os bons costumes.

Aprendi a vê-lo como um combatente, não das causas fáceis, que pouco necessitam de quem as defenda, mas das causas órfãs, essas a que todos se esquivam porque a notoriedale que dão tem o peso do estigma e exultam a desconfiança. Nunca o vi recuar na defesa de uma posição, porque isso the traria beneficios e o pouparia a aborrecimentos. A sua verticalidade advinha-lhe de pautar a sua conduta por um conjunto de valores que colocava em primeiro lugar a liberdade, a dignidade humana, e a igualdade.

Sabia, como poucos, convocar o rigor e exigi-lo aos outros quando a argumentação se enredava nas teias que levam a nenhum lado. Se havia coisas que amasse desmesuradamente a filosofia era uma delas, por isso vivia partilhando essa paixão por um mundo para onde se entra para jamais sair. $E$ fomos muitos os que ao longo de mais de vinte anos descobriram nas suas lições esse mundo e essa paixão.

Lembro-me, porque ainda o oiço, da sageza com abordava a história da filosofia e sem a sobranceria da cátedra nos ouvia tecer considerações que, mesmo quando pouco fundamentadas, nunca mereceram o despeito, mas, pelo contrário, motivavam

1 Citado em Portugues por Danny Sugerman em "No One Here Gets Out Alive". 
um diálogo mais aturado e intermináveis horas de paciência que nunca regateou. Os dias e as noites ligavam-se pelas discussões e nunca vi o cansaço vencer-lhe a lucidez, ou um assomo de fastio perante os que defendessem posições diferentes das suas. Mas, porque era exigente, consigo em primeiro lugar, e com aqueles a que a amizade o ligava, logo a seguir, sempre jogou às claras e todos sabíamos que se havia coisas que não tolerava uma era ignorância balofa e, outra, sem quaisquer contemplações, os inimigos da liberdade.

Ao contrário de muitos que recusavam assumir frontalmente o que pensavam acerca da política, da vida ou mesmo da filosofia, para assim se resguardarem contra os possíveis ou imaginários opositores, sempre o ouvi dizer o que pensava porque norteava a sua conduta por uma honestidade intelectual e moral inabaláveis. Se, como gostava de dizer, a vida deve ser um projecto estético, foi também no seu caso e com singular verticalidade um projecto ético.

A sua paixão pela justiça e contra todas as formas de exploração desde muito cedo lhe marcaram o território e o lado exacto da barricada, mas sempre soube distinguir o homem da obra e a relevância que esta poderia ter no acervo da produção filosófica da humanidade. A importância que Heidegger teve no seu percurso filosófico é disso prova inegável. E porque não confundia os planos da obra e do autor, e porque avaliava e apreciava o rigor e a profundidade, não podia deixar de preferir Aristóteles a Platão, São Tomás a Santo Agostinho, Hume a Descartes, Kant a Hegel, Husserl a Nietzsche, Heidegger a Sartre.

Espírito livre e muitas vezes a roçar o libertário nunca se deixou enfeudar em escolas ou em movimentos que lhe coibissem a liberdade e essa arrogância do pensamento pela qual o verdadeiro filosofar deve pugnar acima de tudo.

Vi-lhe por mais de uma vez o olhar emocionado perante a beleza austera, despojada, da arquitectura românica; ouvi-lhe as palavras empolgadas com que se referia a D. Quixote e a Cervantes como o maior entre os maiores; lembro as descrições entendidas da paleta de cores e o olhar único com que via Vélasquez. Mas porque era um homem que viveu o seu tempo também foi tocado pelo rock and roll e por essa insatisfação e revolta que os Stones ou os Doors souberam pôr em música.

Muito mais do que do mestre, sinto uma imensa saudade do homem, porque a amizade, essa fonte que torna apetecível estar vivo, construímo-la muito para além das paredes da Academia e se com ele aprendi muita da pouca filosofia que sei, aprendi, também, e sobretudo, e é isso que daqui lhe agradeço, a ser inteiro.

Muitas vezes trocámos Apolo por Dionísio, e tenho uma imensa pena de não termos trocado mais vezes, porque diga-se o que se disser a vida também é feita disso: dias em que apetece transgredir, dias em que o álcool torna destra a alma, dias em que se aprende a saborear a linguagem das rosas, como já o havia dito Omar kayahm.

Se a filosofia fala da razão, deixem-me pela poesia falar do coração.

Ainda havemos de beber o último copo

E fumar o charuto magnífico

Um dia ouvindo Jim de viva voz

No Cairo ou no porto de Málaga

ou em qualquer lugar sem nome

Desafiando a vida essa puta deslumbrante

que nos abraça para nos largar no abismo

Havemos de revisitar o Alhambra

quando o Sol for vermelho

em todos os requebros das pedras

E saborear quantas cañas o peito aceitar 
Porque não há morte contra o que muito se quer

Havemos de discutir sem fazer epoqué da amizade

Noites sobre noites com estrelas a fustigarem os olhos e o contentamento

de haver quem connosco partilhe o lado mais fulgurante da descoberta Havemos de calcorrear os caminhos por onde desperta a liberdade e cantar o Che com a voz de quem acredita que ainda é possível fazer de cada homem um lugar de dignidade Havemos de banir o que há de gongórico na cidade dos homens para deixar que prevaleça o robusto e verdadeiro românico das pedras que fazem a amizade Havemos de rir outra vez crianças sabendo que não há definitivo fim mas apenas um sobressalto que antecede o recomeço Havemos de nos abraçar todos para não nos perdermos em Córdova e quiçá conquistar o coração do mundo.

Ramada, Junho de 2002 
